\title{
Study on the Basic Service System of Agricultural Insurance in Guizhou Province
}

\author{
Xiongbo Ruan Shaodong Ma Shiyun Guan \\ Guizhou University of Finance and Economics, Guiyang 550025, China
}

\begin{abstract}
To expand the breadth and depth of Guizhou agricultural insurance services, improve the agricultural insurance service system construction at the grass-roots level is an effective measure to solve the problem of the current agricultural development in Guizhou, based on the analysis of the current problems existing in the agricultural insurance, and specific Suggestions to consummate the solution of the agricultural insurance service system construction at the grass-roots level in Guizhou.
\end{abstract}

\section{Keywords}

Agricultural Insurance, Base Service System, Base Network

\section{贵州省农业保险基层服务体系建设研究}

\author{
阮雄波 马绍东 管士云 \\ 贵州财经大学, 贵阳 550025, 中国
}

摘要: 扩大贵州省农业保险服务的广度和深度出发, 完善农业保险基层服务体系建设是解决 目前贵州省农业发展问题的有效举措, 通过分析当前农业保险存在的问题, 并针对性的提出 完善贵州省农业保险基层服务体系建设的解决方案。

关键词：农业保险，基层服务体系，基层网络 


\section{1. preface}

Guizhou province has a Special geography, and climate environment, this lead the agricultural natural disasters are frequent, after the agricultural natural disaster, how to safeguard farmers' life and to ensure agricultural production continue has become a concern of the government and the social from all walks of life. Agricultural insurance can not only effectively disperse risk of agricultural production and living, but also after the disaster in a timely manner to the affected farmers economic compensation, so how to establish and perfect the grass-roots of agricultural insurance service network, improve the government and experts in the insurance depth and insurance density has become the focus of attention. Agricultural insurance primary service network is not only an important carrier of agricultural insurance social management function, but also the basis for realizing rational allocation of agricultural resources and effective dispersion of agricultural disaster risk.

\section{The basic status of the basic service} system of agricultural insurance in

\section{Guizhou province.}

Guizhou province's unique geography, climate, environment not only led to natural disasters, have also led to the entire province insurance service system is not sound, cannot effectively to assist the government and farmers scattered agricultural risk. At present, the basic status of agricultural insurance in Guizhou province is: firstly, agricultural insurance products are single and narrow, which cannot effectively meet the needs of farmers. Second, the development of agricultural insurance work, underwriting, nuclear protection, investigation, claims and other processes lack scientific institutional support; Third, there is insufficient publicity for agricultural risk and agricultural insurance, farmers lack risk prevention awareness, and farmers have insufficient effective demand for agricultural insurance. Four is a slow development of agricultural insurance, grassroots service network is not sound, the survey fee when service personnel professional knowledge is not enough, agricultural insurance business institutions and government departments lack of linkage mechanism, the power and responsibility is unknown.

3. The difficulties faced in the construction of the basic service system of agricultural insurance in Guizhou province

3.1. Agricultural insurance operation main body is single, danger is planted less

Guizhou belong to the more frequent natural disasters area, farmers income is 
not high, lead to farmers low effective demand for agricultural insurance, agricultural insurance business institutions cannot cover a sufficient number of insurance mark, does not build strong the management risk of the insurance funds to diversify its face, therefore agricultural insurance operators to single. The production cycle length and the high risk of agricultural production have resulted in the low number of agricultural insurance products that guizhou province actually operates in the whole province. Natural disasters in guizhou province, the agricultural insurance to launch new products early loss ratio is high and most of the rural surplus labor transfer in to town farmers engaged in agricultural sex production amount have weakened the insurance company for agricultural insurance innovation enthusiasm.

\subsection{There is a lack of linkage mechanism in the basic service system of agricultural insurance}

Agricultural insurance service system construction needs to departments at the grass-roots level of cooperation can be established, but currently existing in Guizhou agricultural insurance service system at the grass-roots level in institutions did not form a reasonable and effective linkage mechanism between individual department to understand the scope of its responsibilities is not clear.
Mainly embodied in the following aspects: first, although set up agricultural insurance working group, but because of the lack of enough authority and effective system arrangement, lead to agricultural insurance group useless; Secondly, due to the changes of government departments and staff, the measures that have been enacted have been discontinued; Third, the division of responsibilities of various departments is unclear, in the actual implementation of the agricultural insurance work to shift away from each other, the work efficiency is greatly reduced. Therefore, how to develop a scientific and reasonable linkage mechanism is the problem that the development of agricultural insurance in guizhou province must face, and also the problem that must be solved to establish and improve the basic service system.

\subsection{Insufficient number of basic service providers}

The insurance offices and sales department by the end of 2015 in guizhou province in 385 , far cannot satisfy the agricultural demand for insurance services, but the number and quality of agricultural insurance to the employees knowledge high demand, farmers lack of insurance knowledge, seasonal agricultural production and agricultural management, such as small scale and decentralized work determines to carry out the agricultural insurance is a 
complicated and difficult task, therefore the guizhou province insurance business departments and offices far cannot satisfy the needs of development of agricultural insurance. So set up a situation that is known as the rural grass-roots, and have special knowledge of agricultural insurance services team, build a matching grassroots service network to provide support for agricultural insurance work become necessary.

\section{Study on the countermeasures for} the construction of agricultural insurance base service system in Guizhou province

\subsection{To enhance the innovation of dangerous types and business models}

Regions on the basis of successful experience at home and abroad for reference, through field research, combined with their own actual situation, on the basis of the traditional agricultural insurance business model, in view of the farmers demand innovation of insurance products for the farmers to purchase ability and production. In addition, different insurance rates are determined according to the frequency and loss of different natural disasters in each region, and the risk of diversification is distributed to solve the problem of high loss rate.

\subsection{The relevant departments have established a linkage mechanism to clarify responsibilities and promote cooperation}

Basic-level governments at all levels is an important participant of agricultural insurance service system at the grass-roots level, so the grass-roots government should and underwriting insurance institutions to establish linkage mechanism of agricultural insurance, common improve agricultural insurance service system at the grass-roots level: first, the basic people's government should play the role of commanding the whole situation, establish and improve various departments of cooperation and information sharing system; Second, the insurance bureau and other units should supervise and guide the agricultural insurance work in the process of agricultural insurance work in the primary service units, and maintain the orderly operation of agricultural insurance. Finally, the departments clearly define the limits of their rights and responsibilities and ensure that all levels of government departments have to clear their respective insurance responsibilities and obligations with agricultural insurance operators.

\section{3. mprove the basic service network of rural insurance}


First of all, the provincial government should encourage local governments at all levels according to the condition of local agricultural insurance work, can be appropriately increased to arrange some special agricultural insurance work, promotion of agricultural insurance on a regular basis, increase publicity of agriculture insurance, to support agricultural insurance can better and faster development in Guizhou; Second, the local government should through the regular training of insurance professionals and random inspection methods such as support for agricultural insurance business institutions set up and improve the grass-roots service network, for the majority of farmers to provide more quality services; Thirdly, the insurance companies that carry out agricultural insurance should also establish cooperative relations with grassroots agricultural technology promotion departments, seek professional technical support and reduce risks in agricultural insurance. Finally, the agricultural insurance institutions strengthen the enterprise culture construction of the three farmers, enhance the social responsibility of enterprises, and pay attention to the selection and training of grass-roots staff.

\section{References:}

[1] Zundong Zhang ,Cai Chen. The Dilemma of Agricultural Ansurance Development in Guizhou Province and Support Policy Research [J]. Journal of Guizhou University (social science edition), 2013 (4).

[2] The Implementation pPan of Policy-Based Agricultural Insurance in Guizhou Province in 2015.

[3] Zhenwei Qian. The Theory of Agricultural Insurance in The Construction of Grass-Roots Service System of Local Government and The Market Relations, Based on The Investigation of Yuxi city, Yunnan Province Practice [C]. Proceedings of International Conference 2012 Chinese Insurance and Risk Management .

[4] Dongsheng Tian, Hongqiang Yan,Degui Zhang. Extensive Publicity Has Been Deployed to Promote The Rapid Development of Agricultural Insurance [J] 2011 (7).

[5] Huiying Zhang .Research on The Agricultural Insurance Service System in Yunnan [D] Yunnan University of Finance and Economics, May 2013. 